\title{
DINAMIKA BARU DALAM PEMULIHAN ASET AKIBAT KORUPSI DI INDONESIA
}

\section{Rosita Miladmahesi ${ }^{1}$}

\begin{abstract}
The dynamics in assets recovery due to criminal acts of corruption are felt quite a lot of difficulties. Returns of state financial losses due to criminal acts of corruption often do not produce appropriate results. This is due to the many obstacles in solving cases. Especially if certain things make law enforcement officials unable to prosecute crimes, even though there has been a real loss of state finances. Asset recovery efforts are slowly starting to shift from a penal mechanism, to non-penal. This is due to the awareness that law enforcement on conventional criminal acts can no longer cope with state financial losses and asset recovery. Because after all, assets associated with corruption become vital for the life of the nation and state. So that the recovery of assets is one of the priorities in law enforcement. The introduction of various new paradigms in the seizure of assets offered by international conventions and national legal policies to date has experienced problems due to the unequal meaning and the mechanism of appropriation..
\end{abstract}

Keywords : Assets, Corruption, Dynamics, Recovery

\begin{abstract}
Abstrack
Dinamika dalam pemulihan aset akibat tindak pidana korupsi dirasa cukup banyak mengalami kesulitan. Pengembalian kerugian keuangan negara akibat tindak pidana korupsi seringkali tidak memberikan hasil yang sesuai. Hal ini dikarenakan banyaknya hambatan dalam penyelesaian kasus. Apalagi jika ada hal-hal tertentu yang membuat aparat penegak hukum tidak dapat melakukan penuntutan secara pidana, padahal telah ada kerugian keuangan negara yang nyata. Upaya pemulihan aset perlahan mulai bergeser dari mekanisme penal, menjadi non-penal. Hal ini dikarenakan adanya kesadaran, bahwa penegakan hukum atas tindak pidana korupsi secara konvensional tidak lagi dapat menanggulangi kerugian keuangan negara dan pemulihan aset. Karena bagaimanapun juga, aset yang terkait dengan tindak pidana korupsi menjadi hal yang vital bagi kehidupan berbangsa dan bernegara. Sehingga ikhwal pemulihan aset menjadi salah satu prioritas dalam penegakan hukum. Pengenalan berbagai paradigma baru dalam perampasan aset yang ditawarkan oleh konvensi internasional dan kebijakan hukum nasional hingga saat ini masing-masing mengalami permasalahan karena tidak seragamnya pemaknaan serta mekanisme perampasan aset.
\end{abstract}

Kata Kunci : Aset, Dinamika, Korupsi , Pemulihan

\footnotetext{
${ }^{1}$ Fakultas Hukum Universitas Atma Jaya Yogyakarta, rositamilatmahesi@gmail.com
} 


\section{A. Latar Belakang}

Di Indonesia, secara umum korupsi dapat dikelompokkan menjadi dua bagian besar. Bagian pertama adalah penyimpangan pengelolaan dan pertanggungjawaban keuangan negara (APBN), sedangkan bagian berikutnya adalah perbuatan melanggar hukum yang merugikan keuangan negara non APBN. ${ }^{2}$ Transparancy International memberikan definisi tentang korupsi sebagai perbuatan menyalahgunakan kekuasaan dan kepercayaan publik untuk kepentingan pribadi (an abuse of entrusted power for private gain). ${ }^{3}$ Tindak pidana korupsi pada hakikatnya mengandung aspek yang luas, korupsi tidak hanya menyangkut aspek ekonomis yaitu dengan merugikan keuangan Negara dengan memperkaya diri sendiri atau orang lain, mengingat aspek yang sangat luas itu, sering dinyatakan bahwa tindak pidana korupsi terkait dengan economic crime organized crime, illicit drug trafificking. ${ }^{4}$

Adapun Baharuddin Lopa yang mengutip pendapat dari David M. Chalmers, menguraikan istilah korupsi dalam berbagai bidang, yakni yang menyangkut masalah penyuapan, yang berhubungan dengan manipulasi di bidang ekonomi, dan yang menyangkut bidang kepentingan umum. Hal ini diambil dari definisi "financial manipulation and deliction in jurious to the economy are often labeled corrupt". ${ }^{5}$ Oleh karenanya, tindak pidana korupsi selalu mendapatkan sorotan lebih ketimbang tindak pidana khusus lainnya. Tentu saja hal ini dikarenakan efek yang disebabkan oleh korupsi sangat meluas dan mempengaruhi hampir segala aspek kenegaraan.

Tindak pidana korupsi, yang selanjutnya disebut sebagai korupsi telah mendapatkan perhatian khusus di mata masyarakat. Efek berlipat ganda yang disebabkan membuat korupsi meraih predikat sebagai kejahatan luar biasa atau extraordinary crime. Selain itu, korupsi juga dipandang sebagai tindak pidana white collar crime atau kejahatan kerah putih karena korupsi yang terjadi cenderung dilakukan oleh orang-orang cerdas yang rata-rata mengenyam pendidikan tinggi. Terdapat berbagai kelemahan dan kelebihan di dalam penegakan hukum mengenai tindak pidana korupsi. Keberadaan aturan tentang penegakan hukum atas tindak pidana korupsi dinilai belum lengkap dan belum cukup untuk menangani tindak pidana tersebut. Salah satu faktor yang nyata adalah tindak pidana korupsi telah berada jauh beberapa langkah di depan sebelum terbentuknya aturan. Secara tidak langsung mulai menuntut disiplin dan etos kerja untuk harus sudah ada terlebih dahulu ketimbang pengadaan peraturannya.

Berbagai jenis upaya pun mulai dilaksanakan untuk menanggulangi tindak pidana korupsi dan berbagai kejahatan keuangan lainnya. Belakangan ini telah terjadi

\footnotetext{
2 Diana R. W. Napitupulu, 2010, KPK in Action, Penerbit Raih Asa Sukses, Jakarta, hlm..9.

${ }^{3}$ Pope dalam Igm Nurdjana, 2010, Sistem Hukum Pidana dan Bahaya Laten Korupsi "Prespektif Tegaknya Keadilan Melawan Mafia Hukum”, Pustaka Pelajar, Yogyakarta, hlm. 15.

4 Barda Nawawi Arief, 2001, Masalah Penegakan Hukum dan Kebijakan Penanggulangan Kejahatan, Citra Aditya Bakti, Bandung, hlm. 131.

5 Pendidikan Anti Korupsi dalam Ruslan Renggong, 2017, Hukum Pidana Khusus: Memahami Delik-Delik di Luar KUHP, Kencana, Jakarta, hlm 61.
} 
pergeseran paradigma dalam penanggulangan kejahatan keuangan dan turunannya. Hal ini dirasakan oleh aparat penegak hukum beserta jajaran pemerintah, karena ternyata hanya berpatokan kepada penangkapan pelaku kejahatan saja, tidaklah cukup. Pengembalian aset melalui mekanisme pemulihan aset, baik itu dari penyitaan atau perampasan, juga telah memasuki urgensi tersendiri.

Apabila membicarakan mengenai pemulihan aset kerapkali dikaitkan dengan keberadaan tindak pidana korupsi. Namun, pemulihan aset pada tindak pidana korupsi dianggap sebagai prosedur yang sangat sulit dengan hasil yang kurang maksimal pula. Jika kita membahas mengenai rangkaian tindak pidana korupsi merupakan pembahasan yang tiada habisnya. Semakin lama tindak pidana ini justru melampaui penegakan hukum yang dilakukan oleh banyak negara, salah satunya adalah Indonesia. Berbagai macam problematika dihadapi di dalam penegakan hukum pada tindak pidana korupsi, salah satunya di dalam Asset Tracking and Recovery (ATR) atau pelacakan dan pemulihan aset. Pemulihan aset akibat tindak pidana korupsi terkendala oleh beberapa hal, misalkan dalam hal tersangka atau terdakwa menghilang meninggal, melarikan diri, maupun diputus bebas oleh pengadilan dan lain sebagainya, yang dapat mengganggu kinerja penegak hukum dalam mengembalikan aset negara yang di korupsi. Belum lagi dengan permasalahan mengenai eksekusi dalam penyitaan aset yang tidak dapat dilaksanakan (non-eksekutabel).

Mencermati perkembangan tindak pidana korupsi yang selama ini semakin rumit diperlukan strategi yang bersifat masif berkaitan dengan pemberantasan tindak pidana korupsi yang sejatinya merupakan suatu kajian terkini namun bersifat klasik. Sehingga dibutuhkan suatu konsepsi kebijakan penanggulangan kejahatan integral yang mengandung konsekuensi bahwa segala usaha yang rasional untuk menanggulangi kejahatan harus merupakan satu kesatuan yang terpadu. Ini berarti kebijakan untuk menanggulangi kejahatan dengan menggunakan sanksi pidana, harus pula dipadukan dengan usaha-usaha lain yang bersifat non penal. Usaha-usaha non penal ini adalah memperbaiki kondisi-kondisi sosial tertentu yang secara tidak langsung mempunyai pengaruh preventif terhadap kejahatan. ${ }^{6}$

Pemberantasan korupsi dewasa ini difokuskan kepada tiga isu pokok yaitu: pencegahan, pemberantasan dan pengembalian aset hasil korupsi (asset recovery). ${ }^{7}$ Sehingga pemulihan aset akibat tindak pidana korupsi merupakan hal yang penting untuk dilaksanakan. Mengingat, bahwa aset yang dimaksud merupakan milik publik, dan apabila aset tersebut dicuri, harus dikembalikan kepada pemilik sahnya. Baik milik negara, privat maupun perseorangan

\footnotetext{
${ }^{6}$ Barda Nawawi Arief, 2010, Kebijakan Legislatif dalam Penanggulangan Kejahatan dengan Pidana Penjara, Genta Publishing, Yogyakarta, hlm. 34.

${ }^{7}$ Augustinus Pohan, et all., 2008, Pengembalian Aset Kejahatan, Pusat Kajian Anti Korupsi Fakultas Hukum Universitas Gadjah Mada, Yogyakarta, hlm. 1.
} 
Upaya untuk memulihkan kerugian keuangan negara akibat terjadinya tindak pidana korupsi, merupakan salah satu dari sekian prioritas negara untuk menuntaskannya. Urgensi untuk mengembalikan aset negara tersebut pun telah diatur di dalam United Convention Againts Corruption (UNCAC) tahun 2003, yang salah satu tujuan dalam menanggulangi kejahatan keuangan yang marak terjadi di negara pihak, salah satunya adalah Indonesia. Cara-cara pengembalian aset yang diatur di dalam UNCAC sendiri, ada yang melalui cara pidana maupun non-pidana. Namun, terdapat kesulitan dalam pemulihan aset di Indonesia dipengaruhi oleh beberapa hal, seperti : kurangnya wadah hukum yang ideal dalam hal perampasan aset, faktor-faktor lain yang ada di dalam diri tersangka maupun terdakwa, serta kurang seragamnya pemaknaan pada perampasan aset oleh aparat penegak hukum. Selain itu, terdapat pula tantangan penerapan perampasan aset yang dianut di UNCAC apabila diimplementasikan dalam sistem hukum nasional Indonesia.

\section{B. Rumusan Masalah}

Dari latar belakang permasalahan di atas maka dibentuklah rumusan masalah sebagai berikut:

1. Bagaimana kebijakan serta mekanisme perampasan aset yang dimiliki oleh Indonesia saat ini?

2. Apa saja paradigma baru dan tantangan pada perampasan aset di Indonesia?

3. Apakah konstruksi hukum yang dapat menjadi solusi dalam perampasan dan pemulihan aset di Indonesia?

\section{Kebijakan Hukum Perampasan Aset di Indonesia}

Kendala pada penegakan hukum di Indonesia adalah masalah pengembalian aset koruptor yang telah terintegrasi di luar kompetensi penegakan hukum Indonesia. Pengembalian aset dalam yurisdiksi nasional dari pelakunya saja sering kali mengalami kendala sistem nasional. Apalagi terhadap pengembalian aset hasil korupsi yang bersifat transnasional atau lintas negara. ${ }^{8}$ Selain kendala di atas, masih juga terdapat beberapa kendala-kendala lainnya, yang sebenarnya sangat inovatif dalam segi teoritis, namun sangat sulit bahkan hampir tidak mungkin untuk dipraktikkan. Pada prinsipnya, Undang-Undang Nomor 20 Tahun 2001 tentang Perubahan atas Undang-Undang Nomor 31 Tahun 1999 tentang Pemberantasan Tindak Pidana Korupsi sebagaimana telah diubah dengan Undang-Undang Nomor 30 Tahun 2002 tentang Komisi Pemberantasan Tindak Pidaa Korupsi (UU PTPK), dengan kaitannya terhadap perampasan aset akibat tindak pidana korupsi, sudah mengatur jalur pidana maupun non pidana.

\footnotetext{
${ }^{8}$ Indriyanto Seno Adji, 2009, Korupsi dan Penegakan Hukum, Diadit Media, Jakarta, hlm. 149.
} 
UU PTPK telah mengatur ketentuan mengenai pembalikan beban pembuktian terhadap perolehan harta kekayaan. Dalam hal terdakwa tidak dapat membuktikan tentang penambahan kekayaannya, maka keterangan tersebut dapat digunakan untuk memperkuat alat bukti yang sudah ada bahwa terdakwa telah melakukan tindak pidana korupsi. Ketentuan pembalikan beban pembuktian dalam UU PTPK dilakukan dalam proses perkara pidana dan dikaitkan dengan proses pidana itu sendiri. Sehingga apabila terdakwa dibebaskan atau dinyatakan lepas dari segala tuntutan hukum dari perkara pokok, maka tuntutan perampasan harta benda harus ditolak oleh hakim. ${ }^{9}$

Terdakwa wajib membuktikan bahwa perbuatan yang dilakukan tidaklah sebagai perbuatan yang melawan hukum (korupsi). Dengan meletakkan beban pembuktian kepada Terdakwa, maka asas yang diberlakukan dalam tindak pidana korupsi ini-pun beralih dari "presumption of innoncence" (praduga tak bersalah) menjadi "presumption of corruption" (praduga korupsi) atau "presumption of guilt" (praduga bersalah). Karena itu sering dikatakan bahwa penerapan sistem pembalikkan beban pembuktian merupakan potensi terjadinya pelanggaran Hak Asasi Manusia yang prinsip sekali. ${ }^{10}$

Kemudian, untuk mekanisme untuk melakukan perampasan aset dengan jalur nonpidana, seperti pengajuan gugatan secara perdata dalam hal kerugian keuangan negara yang diduga telah nyata dan terjadi. Hal ini diatur di dalam Pasal 32, Pasal 33, Pasal 34, serta Pasal 38C UUPTPK. Pada empat pasal ini, diketahui bahwa gugatan perdata terhadap kerugian keuangan negara dapat dilakukan apabila:

1. Tidak terdapat cukup alat bukti untuk menuntut tersangka atau terdakwa secara pidana, padahal telah terdapat kerugian keuangan negara yang nyata.

2. Putusan bebas terhadap terdakwa.

3. Tersangka meninggal dunia dan gugatan perdata ditujukan kepada ahli waris.

4. Terdakwa meninggal dunia dan gugatan perdata ditujukan kepada ahli waris.

Gugatan perdata juga masih dimungkinkan apabila telah terdapat putusan pengadilan yang berkekuatan hukum tetap secara pidana, dan diduga maupun diketahui masih terdapat aset yang belum dikenai perampasan aset. Negara melalui aparat penegak hukumnya pun berhak untuk mengajukan gugatan perdata kepada ahli waris, jika dalam persidangan terdakwa tidak dapat membuktikan asal-usul harta kekayaan yang dimilikinya.

Dapat dilihat bahwa di dalam ketentuan pada UU PTPK telah memberikan dasar bagi Jaksa Penuntut Umum (JPU) dan Jaksa Pengacara Negara (JPN) untuk mengajukan tuntutan atau gugatan perampasan aset dalam perkara korupsi bagi terdakwa yang karena suatu hal tertentu tidak dapat diadili dan kepada ahli waris

\footnotetext{
${ }^{9}$ Lihat Pasal 37 ayat (4) dan Pasal 37 B UU PTPK.

${ }^{10}$ Indriyanto Seno Adji , Op.cit, hlm. 282.
} 
terdakwa. Kemudian, pada tahap pro-justicia, apabila belum diperoleh alat bukti yang cukup namun telah diketahui atau diduga telah terjadi kerugian keuangan negara, maka JPN dapat melakukan gugatan pengembalian kerugian keuangan negara berdasarkan pelimpahan berkas pro-justicia.

Dalam perkembangannya, muncul beberapa pengaturan mengenai perampasan aset kejahatan baik yang diatur secara umum di dalam KUHP dan KUHAP, maupun diatur secara khusus, misalnya di Undang-Undang Nomor 8 Tahun 2010 tetang Pencegahan dan Pemberantasan Tindak Pidana Pencucian Uang (TPPU), Peraturan Mahkamah Agung Nomor 1 Tahun 2013 tentang Tata Cara Penyelesaian Permohonan Penanganan Harta Kekayaan dalam Tindak Pidana Pencucian Uang dan Tindak Pidana Lainnya. Terkait dengan pengembalian aset kejahatan di luar negari maka muncul pula beberapa legislasi baru mengenai perampasan aset kejahatan dalam kaitannya dengan bantuan hukum timbal balik melalui Undang-Undang Nomor 1 Tahun 2006 tentang Bantuan Hukum Timbal Balik Dalam Masalah Pidana dan Ratifikasi Konvensi Anti Korupsi melalui Undang-Undang Nomor 7 Tahun 2006 tentang Ratifikasi UNCAC. ${ }^{11}$

Sistem hukum Indonesia saat ini belum memiliki ketentuan khusus mengenai perampasan aset tindak pidana. Konsep perampasan aset yang ada saat ini adalah perampasan aset berdasarkan sistem hukum pidana Indonesia melalui putusan pengadilan yang telah memiliki kekuatan hukum tetap (inkracht). Ketentuan tersebut diatur di dalam Pasal 39 ayat (1) dan ayat (2) KUHAP dan Pasal 18 ayat (1) huruf a UU PTPK. Selain didasari atas putusan pengadilan yang telah memiliki kekuatan hukum tetap (inkracht), perampasan aset hasil tindak pidana dapat dilakukan melalui gugatan perdata sebagaimana diatur dalam Pasal 32, 33, 34, dan UU PTPK. ${ }^{12}$

Pada saat ini, terdapat dua mekanisme penyelenggaraan perampasan aset di Indonesia yang ditempuh dalam proses pengembalian aset hasil tindak pidana korupsi. Pertama, dengan melakukan pelacakan, selanjutnya aset yang sudah berhasil dilacak dan diketahui keberadaannya kemudian dibekukan. Kedua, aset yang telah dibekukan itu lalu disita dan dirampas oleh badan yang berwenang dari negara di mana aset tersebut berada, dan kemudian dikembalikan kepada negara tempat aset itu diambil melalui mekanisme-mekanisme tertentu. ${ }^{13}$

\section{Tantangan Implementasi dan Penerapan UNCAC dan Non-Conviction Based (NCB) on Asset Forfeiture di Indonesia}

Perkembangan dari berbagai pola organized crime baik di Indonesia maupun diseluruh dunia memberikan tantangan tersendiri bagi masing-masing rezim pemerintahan negara. Organized crime menjadi fenomena tersendiri, dan pengusutan

11 Muhammad Yusuf, 2013, Merampas Aset Koruptor: Solusi Pemberantasan Korupsi di Indonesia, PT.Kompas Media Nusantara, Jakarta, hlm. 227-228.

12 Ibid, hlm.231-232.

${ }^{13}$ Romli Atmasasmita dalam Muhammad Yusuf, Ibid, hlm. 224. 
serta pemberantasannya bukanlah hal yang mudah. Pola konvensional yang diterapkan melalui pengejaran antek-antek kejahatan ataupun pimpinannya masih sering mengalami berbagai kegagalan dan hambatan. Sehingga, pemilihan konsepsi "mengejar aset" ketimbang "mengejar para pelaku" mulai dinilai sebagai terobosan dalam dunia penegakan hukum.

Konstruksi yang diketahui oleh masyarakat berbagai kalangan beserta penegak hukum dalam hal perbuatan pidana dewasa ini, masih menggunakan pandangan bahwa harus terdapat pembuktian kesalahan terlebih dahulu sebelum tersangka maupun terdakwa yang bersangkutan dapat mempertanggung-jawabkan perbuatannya. Baik bertanggung-jawab melalui pemidanaan, denda, penyitaan aset ataupun perampasan aset dan sebagainya. Hal ini dikarenakan kentalnya prinsip presumption of innoncence dalam penegakan hukum di Indonesia, terkhusus dalam persidangan pidana. Karena pada dasarnya, hukum pidana adalah hukum yang sanksinya sangat berat dengan sifatnya sebagai ultimatum remidium. Jadi tidak sembarangan seseorang bisa dituduh melakukan perbuatan pidana. Pada prinsip di dalam hukum pidana murni, tentu saja segala sebab-akibat, serta pertanggungjawaban dilimpahkan kepada pelaku (in personam). Model ini disebut sebagai model criminal forfeiture, dan masih berlaku hingga sekarang. Pelaksanaan criminal forfeiture tentu saja didasarkan pada adanya bentuk kesalahan oleh pelaku (perbuatan pidana) dan pelaku tersebut tidak dapat dinyatakan bersalah sebelum adanya putusan pengadilan yang berkekuatan hukum tetap, sehingga hak-hak dari pelaku juga terjamin oleh hukum.

Perbuatan pidana hanya menunjuk kepada dilarang dan diancamnya perbuatan dengan suatu pidana. Apakah orang yang melakukan perbuatan kemudian juga dijatuhi pidana, sebagai mana telah diancamkan, ini tergantung dari soal apakah dalam melakukan perbuatan ini dia mempunyai kesalahan hal ini disebabkan adanya asas pertanggung-jawaban (Geen straf zonder schuld; Actus non facit reum nisi mens sist rea). ${ }^{14}$ Sedangkan pertanggung-jawaban tanpa adanya kesalahan dari pihak yang melanggar, dinamakan leer van het materiele feit (fait materielle). ${ }^{15}$

Namun perlu dipahami bahwa pemberantasan korupsi atau kejahatan keuangan lainnya, tidak cukup dengan menghukum para pelakunya, namun harus diimbangi dengan upaya untuk memotong aliran hasil kejahatan. Dengan merampas harta benda yang dihasilkan dari kejahatan korupsi maka diharapkan pelaku akan hilang motivasinya untuk melakukan atau meneruskan perbuatannya, karena tujuan untuk menikmati hasil-hasil kejahatannya akan terhalangi atau menjadi sia-sia. ${ }^{16}$ Pemberian hukuman adalah tidak cukup, untuk itu, dengan atau disertai perampasan aset melalui penyitaan hasil tindak pidana akan memberikan dampak dan pengaruh yang signifikan terhadap calon pelaku tindak pidana. Mereka akan takut jika semua keuntungan hasil

14 Moelyatno, 2015, Asas-Asas Hukum Pidana, PT. Rineka Cipta, Jakarta, hlm.165.

15 Ibid.

${ }^{16}$ Basrief Arief, 2014, Pemulihan Aset Hasil Kejahatan dalam Pemberantasan Tindak Pidana Korupsi, Workshop Pemulihan Aset Tindak Pidana, Jakarta, hlm. 1. 
tindak pidana akan disita oleh Negara, tanpa harus melalui peradilan pidana. ${ }^{17}$ Salah satu mekanisme perampasan aset tanpa melalui peradilan pidana, dapat menggunakan civil forfeiture. Civil forfeiture adalah mekanisme pengembalian aset yang dilakukan oleh negara dengan menggunakan gugatan secara perdata (tanpa tuntutan pidana) terhadap aset yang dimiliki oleh pelaku kejahatan.

Model pembuktian perdata ini berlandaskan prinsip prepondance of evidence, dimana suatu kebenaran semata-mata didasarkan pada alat bukti mana yang lebih meyakinkan atau dapat diukur dengan siapa yang memiliki bukti lebih banyak dan pihak yang harus membuktikan adalah pihak yang menyatakan atau menuntut hak tersebut. Maka, dalam perampasan perdata ini, keyakinan hakim tidak dibutuhkan untuk menentukan suatu harta kekayaan merupakan hasil tindak pidana, karena standar pembuktian yang sudah diturunkan dari standar pembuktian pidana ke perdata. ${ }^{18}$

Pada dasarnya, mekanisme civil forfeiture dapat memiskinkan pelaku sampai kepada titik si pelaku tidak memiliki aset ataupun harta benda lainnya. Penyitaan jenis ini lebih mengedepankan hak secara publik dengan pertimbangan bahwa aset yang diambil oleh pelaku merupakan aset negara dan warga negara. Dengan akibat kepada pelaku yang sedemikian rupa, dapat dikatakan bahwa perampasan aset dengan cara civil forfeiture memiliki potensi pelanggaran hak asasi manusia. Sehingga pelaksanaan perampasan aset dengan cara civil forfeiture sebaiknya dilakukan sebagai alternatif saja, ketika jalur pidana sama sekali tidak dapat dilaksanakan.

Teori pengembalian aset merupakan bagian terpenting dari hukum anti korupsi dalam bentuk yang berakar pada esensi paling dalam dari hukum anti korupsi, terutama dalam fungsinya mengupayakan pengembalian aset hasil hasil tindak pidana korupsi kepada negara korban, mencegah pelaku melakukan tindak pidana lain dengan menggunakan aset tersebut. ${ }^{19}$

Pemulihan aset dalam kejahatan keuangan (apalagi korupsi), merupakan salah satu konsekuensi dari prinsip negara hukum. Dapat dikatakan bahwa, pemulihan aset ini adalah tanggung jawab negara dalam mewujudkan kesejahteraan rakyat. Sulitnya pemulihan aset dalam tindak pidana korupsi tak hanya dialami oleh Indonesia, banyak negara yang juga mengalami hal tersebut, hal tersebutlah yang melatar-belakangi keberadaan konvensi UNCAC. Dengan kesulitan yang cenderung sama antara negara pihak, maka di dalam UNCAC, tepatnya di dalam Pasal 54 ayat (1) huruf c menyatakan bahwa:

17 AR. Suhariyono, 2014, Rancangan Undang-Undang tentang Perampasan Aset Tindak PIdana, Workshop Pemulihan Aset Tindak Pidana, Jakarta, hlm. 3.

18 Rahmayanti, Urgensi Civil Forfeiture Untuk Meningkatkan Pengembalian Kerugian Keuangan Negara, Jurnal Ilmu Hukum Prima Indonesia (IHP), Vol.1, No.1, April 2018, hlm. 6.

19 Bibianus Hengky Widhi Antoro, 2014, Tesis, "Kebijakan Integral Pemberantasan Tindak Pidana Korupsi Melalui Asset Recovery”, Fakultas Hukum Universitas Sebelas Maret, Surakarta, hlm. 35. 
“.. Each State Party ... shall, in accordance with its domestic law: Consider taking such measures as may be necessary to allow confiscation on such property without a criminal conviction in cases in which the offender cannot be prosecuted by reason of death, flight or absence or in other appropriate cases."

Pernyataan diatas bilai diterjemahkan memiliki pengertian bahwa seluruh negara pihak wajib sesuai dengan hukum domestiknya agar mempertimbangkan untuk mengambil tindakan-tindakan yang perlu untuk memungkinkan perampasan kekayaan tanpa disertai dengan penghukuman pidana dalam kasus-kasus yang pelakunya tidak dapat dituntut karena meninggal dunia, melarikan diri atau tidak ditemukan atau di dalam kasus lain yang sesuai.

Non-Conviction Based on Asset Forfeiture (NCB Asset forfeiture) atau perampasan aset tanpa tuntutan pidana juga termuat di dalam UNCAC. Konsep NCB Asset forfeiture menggunakan cara bahwa perampasan aset dalam kejahatan yang melibatkan keuangan, tidaklah perlu menunggu putusan pengadilan yang telah memiliki kekuatan hukum yang tetap. Hal ini dikarenakan, dalam NCB Asset forfeiture lebih berfokus kepada pengejaran aset (in rem) dan bukan pelaku (in personam). Pada penerapannya, konsep NCB Asset forfeiture ini merupakan konsep baru yang cukup menggeser paradigma bahwa perampasan aset harus dilakukan berdasarkan tuntutan pidana dan putusan pengadilan yang berkekuatan hukum tetap.

NCB Asset forfeiture memiliki konsepsi dasar yang sama seperti aturan-aturan lainnya. NCB Asset forfeiture ini memiliki subjek dan juga objek. Subjek yang disasar oleh NCB Asset forfeiture tentu saja merupakan pihak yang memiliki kepentingan terhadap aset. Sedangkan yang dijadikan objek oleh NCB Asset forfeiture adalah seluruh aset yang berupa harta kekayaan pribadi, orang lain, korporasi, serta harta kekayaan yang diduga kuat berkaitan dengan tindak pidana, aset yang dimiliki oleh subjek yang antara penghasilan dan kekayaannya tidak seimbang, harta kekayaan yang tidak dapat dibuktikan asal-usul perolehan secara sah oleh subjek, harta kekayaan yang diduga didapatkan dari hasil tindak pidana serta temuan yang diduga berasal dari tindak pidana.

Sebenarnya konsep NCB Asset forfeiture tidaklah murni berasal dari UNCAC, namun melalui sejarah panjang pada penegakan hukum di negara-negara dengan tradisi hukum common law, seperti Inggris dan Amerika. Di dalam penegakan hukum pada kejahatan keuangan di negara common law, apalagi menggunakan NCB Asset forfeiture dalam perampasan asetnya merupakan hal yang cukup lumrah dilaksanakan. Hanya saja, pemberlakuan NCB Asset forfeiture di negara-negara common law, terkhusus Amerika, lebih sering digunakan dalam kasus-kasus yang menjurus kepada illicit enrichment dan unexplained wealth dalam kasus tindak pidana narkotika. Karena di dalam tindak pidana narkotika di negara tersebut, jaringan narkotika cukup besar dan sulit diberantas, sedangkan keuntungan dari tindak pidana tersebut sangatlah besar. 
Mekanisme NCB Asset forfeiture tidak perlu menunggu keberadaan tuntutan maupun putusan pengadilan yang berkekuatan hukum tetap, karena prinsip pada NCB Asset forfeiture tidak menggunakan beyond reasonable doubt ataupun menggunakan prinsip pembuktian secara negatif (negative-wettellejke), namun penegak hukum cukup menunjukkan adanya probable cause (pembuktian formil). Singkatnya, hubungan yang dikejar dalam perampasan aset pada NCB Asset forfeiture bukan antara pelaku dengan tindak pidana, melainkan antara tindak pidana dengan aset. Aset yang dimaksud disini tentu saja merupakan aset yang diduga telah "tercemar" dengan suatu tindak pidana tertentu.

Sebagai salah satu negara pihak yang terikat ke dalam konvensi UNCAC dengan ratifikasi melalui Undang-Undang Nomor 7 Tahun 2006 tentang Pengesahan UNCAC, otomatis membuat Indonesia terikat dengan segala ketentuan pada konvensi. Meskipun terikat dengan ketentuan pada konvensi, Indonesia juga masih mempertimbangkan hukum domestik dan kedaulatan nasionalnya. Sehingga pada tahun 2012 yang lalu, mulai digagas pembentukan suatu undang-undang khusus untuk mengatur mengenai perampasan aset pada kejahatan keuangan melalui RUU Perampasan Aset. Langkah ini merupakan cara untuk Indonesia beradaptasi terhadap UNCAC, karena sebagaimana yang kita ketahui subtansi NCB Asset Forfeiture di dalam UNCAC diberlakukan dengan tujuan dapat melampaui segala macam hambatan pada tradisi hukum masing-masing negara pihak. Meskipun demikian, pemberlakuan NCB Asset Forfeiture tidak semudah yang dibayangkan.

Jika menggunakan pendekatan perlindungan hak asasi manusia, penerapan NCB Asset forfeiture dapat menimbulkan beragam konflik dan persoalan. Misalkan pada asas praduga tak bersalah, hak terdakwa untuk tidak memberikan keterangan yang memberatkan bagi dirinya (non-self incrimination), serta persoalan tentang kepemilikan aset-aset yang dimiliki oleh tersangka maupun terdakwa. Di dalam Undang-Undang Dasar Negara Republik Indonesia Tahun 1945 yakni pada Pasal 28H ayat (4) menyatakan bahwa: "Setiap orang berhak mempunyai hak milik pribadi dan hak milik tersebut tidak boleh diambil alih secara sewenang-wenang"

Sehingga di dalam UUD 1945 sebagai konstitusi telah menyatakan secara eksplisit bahwa harta maupun aset milik warga negara tidak boleh diambil tanpa adanya aturan hukum yang berlaku. Perampasan diperbolehkan ketika harta atau aset yang dimaksud itu diperoleh dari tindak pidana dan/atau akan dipakai untuk melakukan tindak pidana. Pada prinsipnya, apabila seorang warga negara memiliki kepemilikan terhadap suatu aset tertentu, maka hal tersebut menjadi salah satu kewajiban negara untuk melindungi karena hak milik yang dimiliki oleh warga negara merupakan hak yang sifatnya cukup fundamental, dan sebenarnya negara tidak dapat menyita aset-aset tersebut hanya berdasarkan asumsi maupun dugaan bahwa aset yang dimaksud merupakan aset hasil tindak pidana atau diduga bertalian dengan suatu tindak pidana.

Berkaitan dengan perampasan aset sendiri, Indonesia juga memiliki pengaturan di dalam Undang-Undang Nomor 39 Tahun 1999 tentang Hak Asasi Manusia, yang 
termaktub di dalam Pasal 19 ayat (1) yang menyatakan bahwa: "Tiada suatu pelanggaran atau suatu kejahatan apapun diancam dengan hukuman berupa perampasan seluruh harta kekayaan milik yang bersalah". Sehingga perampasan aset yang dilakukan oleh mekanisme NCB Asset forfeiture berpotensi untuk "memiskinkan" terdakwa atau tersangka hingga titik akhir, dan tentu saja bertentangan dengan aturan diatas.

Jika dilihat, NCB Asset forfeiture dapat menjadi alat yang sangat berguna untuk menyita dan mengambil alih aset dari para koruptor di Indonesia. setidak-tidaknya ada beberapa kegunaan NCB Asset forfeiture untuk membantu aparat penegak hukum dalam proses pengembalian aset para koruptor $^{20}$ :

1. Pertama, NCB Asset forfeiture tidak berhubungan dengan sebuah tindak pidana sehingga penyitaan dapat lebih cepat diminta kepada pengadilan daripada criminal forfeiture.

2. Kedua, NCB Asset forfeiture menggunakan standar pembuktian perdata, karena standar pembuktian perdata relatif lebih ringan ketimbang standar pembuktian pidana. Selain itu, NCB Asset forfeiture juga mengadopsi sistem pembuktian terbalik sehingga meringankan beban pemerintah untuk melakukan pembuktian terhadap gugatan yang diajukan.

3. Ketiga, NCB Asset forfeiture hanya berhubungan dengan aset yang diduga berasal, dipakai atau mempunyai sebuah hubungan dengan suatu tindak pidana. Maka, pelaku tindak pidana itu sendiri tidak relevan, sehingga kaburnya, hilangnya, meninggalnya seorang koruptor atau bahkan adanya putusan bebas untuk koruptor tersebut tidaklah menjadi permasalahan dalam NCB Asset forfeiture.

4. Keempat, NCB Asset forfeiture sangat berguna bagi kasus-kasus di mana penuntutan secara pidana mendapat halangan atau tidak dimungkinkan dilakukan. Dalam upaya pemberantasan korupsi sering kali menghadapi koruptor yang politically well-connected sehingga aparat penegak hukum menghadapi kesulitan dalam mengadilinya.

Namun dengan kelebihan yang sedemikian rupa, tidaklah berarti bahwa NCB Asset forfeiture tidak memiliki kekurangan. Kekurangan yang dimiliki oleh NCB Asset forfeiture antara lain ialah : untuk membuat gugatan NCB Asset forfeiture dibutuhkan suatu keahlian tersendiri dalam mengidentifikasi aset yang akan digugat dan mencari alat bukti untuk membuktikan adanya sebuah dugaan bahwa aset tersebut mempunyai hubungan terhadap sebuah aset. ${ }^{21}$

Selain itu, agar instrumen ini berjalan efektif, perlu adanya sebuah kerja sama baik sesama aparat dan institusi dalam negeri dan negara-negara lain (Mutual Legal

\footnotetext{
${ }^{20}$ Bismar Siregar dan Stefan D. Casella dalam Muhammad Yusuf, Op.Cit, hlm. 158-159.

${ }^{21}$ Bismar Siregar dalam Muhammad Yusuf, Ibid, hlm. 160.
} 
Assistance) terutama untuk mengambil aset-aset yang ada di luar negeri. Kelemahan lainnya adalah mengenai keterbatasan dalam mengambil aset koruptor. NCB Asset forfeiture hanya dapat mengambil alih aset-aset yang terbukti mempunyai dugaan terkait dengan sebuah tindak pidana. Secara umumnya, NCB Asset forfeiture adalah sebuah gugatan untuk mendapat compensatory atau remedial damages bukan bersifat punitive seperti yang diadopsi oleh rezim criminal forfeiture. Sehingga tidak semua kerugian yang dialami pemerintah dari sebuah tindak pidana dapat digantikan oleh instrumen ini. ${ }^{22}$ Keberadaan NCB Asset forfeiture tidaklah semata-mata menggantikan semua mekanisme perampasan aset pada seluruh tindak pidana. Penggunaannya harus dibatasi dan hanya digunakan berdasarkan syarat yang ketat pula.

Jika dilihat sepintas, memang terdapat persamaan antara mekanisme gugatan di dalam UU PTPK dengan NCB Asset forfeiture. Namun, perbedaan yang paling mendasar adalah di dalam UU PTPK masih menggunakan hukum perdata murni dan masih berpegang kepada asas Actori Incumbit Onus Probatio atau "Siapa yang mendalilkan wajib untuk membuktikan", hal ini berbeda dengan konsep gugatan yang ditawarkan di dalam NCB Asset forfeiture, yang menggunakan sistem pembuktian terbalik. Jadi penggugat dalam hal ini adalah pemerintah melalui JPN cukup menyediakan gugatan terhadap aset dan yang menjadi tergugat apabila merasa keberatan dapat membuktikan ke pengadilan bahwa aset yang menjadi objek gugatan bukanlah berasal dari suatu tindak pidana yang dituduhkan.

Tantangan lain selanjutnya, adalah bagaimana cara mengimplementasikan UNCAC terhadap sistem hukum di Indonesia. Sebagai negara pihak dalam UNCAC, Indonesia tentu memiliki kewajiban untuk mengikuti apa yang di instruksikan oleh UNCAC, hal ini telah ditindaklanjuti dengan pengesahan Undang-Undang Nomor 7 Tahun 2006 tentang Ratifikasi UNCAC. Namun permasalahan dalam pengaplikasian norma-norma UNCAC juga mulai berdatangan, permasalahan ini berangkat dari pertanyaan apakah ketika suatu konvensi atau perjanjian internasional telah diratifikasi tersebut: dapat langsung mengikat keseluruhan melalui suatu undang-undang semisal Undang-Undang Nomor 7 Tahun 2006 tentang Ratifikasi UNCAC ataukah harus mulai dimasukkkan ke dalam undang-undang organik yang mengatur perbuatan dan peristiwa terkait, semisal harus dimasukkan ke dalam UU PTPK atau Undang-Undang TPPU?

Pertanyaan tersebut tentu saja memiliki jawaban yang berbeda. Ada yang menyatakan bahwa sepanjang UNCAC telah diratifikasi menjadi undang-undang, maka seketika hal tersebut berlaku mengikat bagi seluruh kalangan termasuk para penegak hukum. Tetapi, ada juga yang menyatakan bahwa norma-norma yang di dalam UNCAC yang telah diratifikasi tersebut harus dimasukkan ke dalam undang-undang organik yang memerlukan norma-norma UNCAC itu.

${ }^{22}$ Ibid. 
Kedua jawaban ini hemat penulis merupakan jawaban yang sama-sama sulit untuk dilaksanakan. Jika mengacu pada jawaban pertama, maka potensi perbedaan persepsi antar penegak hukum akan ada dan hal itu semakin mempersulit penegakan hukum. Kemudian jika mengacu kepada jawaban pertama, maka perlu dilakukan proses perubahan atau revisi terhadap undang-undang organik, demi memasukkan norma UNCAC ke dalamnya. Apalagi masih terdapat perbedaan antara undang-undang organik yang sifatnya sudah lex specialis tersebut. Karena patut diketahui, bahwa masing-masing undang-undang tersebut memiliki rezim dan jiwa yang berbeda. Atas dilema tersebut, maka pemerintah Indonesia pun mulai menggagas RUU Perampasan Aset sebagai aturan yang dapat mengakomodasi perampasan aset dalam kejahatan keuangan.

\section{E. Rancangan Undang-Undang (RUU) Perampasan Aset sebagai Instrumen Perampasan Aset}

Dengan terikatnya Indonesia kepada ratifikasi UNCAC melalui Undang-Undang Nomor 7 Tahun 2006 tentang Ratifikasi UNCAC, maka Indonesia mulai mempertimbangkan untuk mengeluarkan sebuah produk hukum yang sama-sama mengakomodasi tradisi hukum Indonesia dan ketentuan UNCAC. Langkah tersebut pun mulai digagas pada tahun 2012 dengan pengusulan pembentukan RUU tentang Perampasan Aset. Karena jika ditelusuri lebih lanjut, ketentuan mengenai perampasan aset dalam hukum pidana di Indonesia terbagi-bagi menjadi beberapa undang-undang yang sifatnya lex specialis. Kemudian, dalam sistem hukum Indonesia hingga saat ini, masih meletakkan hal perampasan aset ke dalam penjatuhan pidana tambahan. Maksudnya, perampasan aset baru dapat dilakukan ketika sudah terbuktinya suatu tindak pidana dan dikuatkan dengan putusan pengadilan, barulah dilakukan tindakan perampasan aset melalui penyitaan.

Namun dalam hal ini, penulis ingin menekankan bahwa dalam hal penyitaan dan perampasan adalah dua hal serupa namun tak sama. Perbedaan dua hal ini dilihat melalui hak kepemilikan dari aset bersangkutan;

1. Penyitaan berarti aset yang disita adalah aset yang kepemilikannya dimiliki secara penuh oleh si individu.

2. Sedangkan pada perampasan, berarti aset yang dimaksud, kepemilikannya telah beralih menjadi milik negara, namun penguasaannya masih di dalam tangan individu, sehingga penegak hukum harus "menyita/mengambil/merampas" aset tersebut.

Melihat ke dalam naskah akademis pada RUU Perampasan Aset, dapat diketahui bahwa muatan-muatan yang dimiliki oleh naskah akademis pada RUU Perampasan Aset cukup banyak menggeser paradigma penegakan hukum konvensional di Indonesia selama ini. Salah satu subtansi yang cukup menarik adalah, RUU 
Perampasan Aset menawarkan konsep pengejaran aset hasil tindak pidana (in rem) ketimbang pelaku kejahatannya (in personam). Perampasan in rem ini bisa dilihat dalam Pasal 1 angka 8 RUU Perampasan Aset.

Dari konsep tersebut, dapat dilihat bahwa paradigma yang ditawarkan oleh RUU Perampasan Aset cukup melanggar beberapa ketentuan dasar asas-asas hukum yang selama ini dianut di Indonesia, sebut saja seperti asas presumption of innocent (asas praduga tak bersalah; seorang dinyatakan bersalah dan harus bertanggung jawab atas kesalahannya apabila telah dinyatakan demikian oleh hakim) dan asas kepastian hukum melalui putusan pengadilan yang berkekuatan hukum tetap. Dimana dalam mekanisme RUU Perampasan Aset tidak mengutamakan putusan pengadilan sebagai langkah eksekusi untuk memulihkan aset, melainkan mengutamakan mekanisme dalam pengejaran aset baik di tingkat pro-justicia ataupun di tingkat persidangan, tanpa mengutamakan putusan dari hakim.

Dengan kata lain, RUU Perampasan Aset memberikan pembedaan yang signifikan antara aset dan pelaku. Bahkan terdapat kemungkinan, aset yang diduga sebagai hasil kejahatan yang dimaksud menjadi "subjek" di dalam persidangan. Sehingga sifat pemulihan aset yang ditawarkan oleh RUU Perampasan Aset tidak lagi bersifat Memang benar, dalam ihwal perampasan aset, harus dibuktikan terlebih dahulu kesalahan secara pidana dari pelaku, namun dewasa ini ternyata cukup banyak keadaan dimana pembuktian pidana pada pelaku kejahatan tidak dapat dilaksanakan dan masih banyak sekali aset-aset yang tidak dapat dikembalikan ataupun dipulihkan dalam kasus terkait, terutama yang hubungannya dengan kejahatan keuangan.

Perampasan harta hasil kejahatan sebenarnya berakar dari sebuah prinsip keadilan yang paling mendasar. Hal ini disampaikan oleh Peter Alldridge, yang menyatakan bahwa "crime does not pay" dimana suatu kejahatan tidak boleh memberikan keuntungan bagi pelakunya, atau dengan kata lain, seseorang tidak boleh mengambil keuntungan dari aktivitas ilegal yang dilakukan. Dengan didasarkan atas crime does not pay tersebut, Alldridge menambahkan bahwa hal ini bisa menjadi justifikasi dilakukannya pemulihan aset melalui mekanisme perampasan-perampasan aset. ${ }^{23}$

\section{F. Penutup}

Merupakan konsensus sosial menyatakan bahwa tindak pidana korupsi benar-benar merugikan secara masif. Didasarkan kepada perkembangan penegakan hukum dan masyarakat yang ada saat ini, pengejaran pelaku (follow the suspect) dipandang tidaklah cukup efektif untuk memberikan penanggulangan atas segala akibat yang terjadi akibat kerugian keuangan negara. Semakin lama perkembangan teknologi

23 P. Alldridge, 2003, Money Laundering Law: Forfeiture, Confiscation, Civil Recovery, Criminal Laundering and Taxation of Proceeds of Crime, Hart Publishing, Oregon, hlm. 55. 
membuat segala macam jenis tindak pidana menjadi tak terbatas (borderless). Sehingga masih diperlukan aspek penegakan hukum yang melampaui hal-hal tersebut.

Paradigma yang hanya berfokus kepada pemberian hukuman kepada pelaku pidana, terkhusus kepada pelaku tindak pidana korupsi tidak cukup. Karena tetap saja, meskipun pelaku telah dihukum, aset yang menjadi objek dalam tindak pidana juga harus diupayakan untuk kembali seperti semula. Sehingga aspek follow the money jauh lebih efektif untuk merestorasi kerugian keuangan negara. Meskipun telah terdapat pergeseran secara perlahan dalam penegakan hukum pada tindak pidana korupsi, haruslah berbanding lurus dengan keberadaan wadah pengaturan hukum yang sesuai pelaksanaan perampasan aset, baik melalui tuntutan pidana, civil forfeiture ataupun dengan konsep NCB Asset forfeiture, menurut hemat penulis tidak akan menimbulkan permasalahan sepanjang hal ini diatur secara jelas dan tegas dalam peraturan perundang-undangan.

Sesuai dengan pembahasan diatas, penulis menarik kesimpulan bahwa sulitnya penegakan hukum dalam perampasan aset di Indonesia saat ini, ialah:

1. Belum ada aturan khusus untuk melakukan perampasan aset. Peraturan perundangundangan yang mengatur tentang perampasan aset terpecah menjadi banyak aturan yang sifanya lex specialis. masing-masing dari peraturan perundang-undangan tersebut memiliki pemaknaan dan rezim yang berbeda antara satu sama lain.

2. Jika merujuk ke dalam perampasan aset di dalam UU PTPK yakni perampasan aset melalui mekanisme gugatan perdata memiliki kelemahan tersendiri, yang mana di dalam UU PTPK hanya langsung "melempar" perampasan aset yang dimaksud ke dalam mekanisme gugatan perdata. Sedangkan mekanisme peradilan perdata yang dianut di Indonesia masihlah menggunakan prinsip perdata murni, dengan "siapa yang mendalilkan berarti ialah yang membuktikan". Hal ini tentu saja akan mempengaruhi bahkan menyulitkan kinerja bagi penegak hukum, misalkan dalam hal ini adalah JPN. Karena jika tetap berpegang pada asas tersebut, maka JPN akan "mati-matian" untuk melakukan Asset Tracking dan membuktikan tentang kepemilikan aset dari terdakwa serta ahli waris yang bersangkutan di muka pengadilan untuk melakukan perampasan. Apabila Asset Tracking yang dilakukan tidak membuahkan hasil atau tidak maksimal, maka akan memiliki konsekuensi yuridis bahwa aset yang dimaksud tidak dapat dirampas atau dapat dirampas namun tidak maksimal pula hasilnya.

3. Kemudian, jika menggunakan mekanisme perampasan aset secara perdata (civil forfeiture) maka proses pembuktian yang seharusnya digunakan adalah proses pembuktian terbalik. Sehingga baik dari pihak yang memiliki aset dapat membuktikan, begitu pula dengan dengan penegak hukum. Jadi terdapat proses pembuktian yang berimbang, ditambah lagi kinerja penegak hukum juga akan menjadi lebih ringan, karena penegak hukum hanya perlu mengajukan gugatan atas aset dan dapat menunggu maupun menganalisis pembuktian dari pemilik aset. 
Diberlakukannya RUU Perampasan Aset menjadi urgensi tersendiri dalam hal perampasan aset pada tindak pidana. Keberadaan suatu undang-undang yang secara khusus mengatur mengenai perampasan aset akan menghilangkan perbedaanperbedaan mekanisme perampasan aset yang ada di dalam peraturan perundangundangan lainnya. Serta untuk mengatasi permasalahan legalitas dan cara ber-acara, penulis merasa bahwa RUU Perampasan Aset menjadi solusi yang tepat untuk memasukkan baik civil forfeiture maupun NCB Asset forfeiture dapat diberlakukan dan tidak akan bertentangan dengan konstitusi, sepanjang pemberlakuannya didasarkan kepada syarat yang ketat dan terbatas. Selain itu, patut digaris bawahi, bahwasanya pemberlakuan civil forfeiture maupun NCB Asset forfeiture tidak digunakan untuk menggantikan penuntutan pidana dalam hal perampasan aset kejahatan.

\section{Daftar Pustaka}

\section{Buku}

Adji, Indriyanto Seno, (2009), Korupsi dan Penegakan Hukum, Jakarta: Diadit Media Alldridge, P, (2003), Money Laundering Law: Forfeiture, Confiscation, Civil Recovery, Criminal Laundering and Taxation of Proceeds of Crime, Oregon : Hart Publishing,

Moelyatno, (2015), Asas-Asas Hukum Pidana, Edisi Revisi, Jakarta: PT. Rineka Cipta Nawawi, Barda Arief, (2001) Masalah Penegakan Hukum dan Kebijakan Penanggulangan Kejahatan, Bandung: Citra Aditya Bakti

-----------, (2010) Kebijakan Legislatif dalam Penanggulangan Kejahatan dengan Pidana Penjara, , Yogyakarta: Genta Publishin

Napitupulu, Diana R,W, (2010), KPK in Action, Jakarta : Penerbit Raih Asa Sukses

Nurdjana, Igm, 2010, Sistem Hukum Pidana dan Bahaya Laten Korupsi "Prespektif Tegaknya Keadilan Melawan Mafia Hukum”, Yogyakarta : Pustaka Pelajar

Renggong, Ruslan, (2017), Hukum Pidana Khusus: Memahami Delik-Delik di Luar KUHP, Jakarta : Kencana

Yusuf, Muhammad, (2013), Merampas Aset Koruptor: Solusi Pemberantasan Korupsi di Indonesia, Jakarta : PT.Kompas Media Nusantara

\section{Jurnal}

Husein, Yunus, 2019, Penjelasan Hukum Tentang Perampasan Aset Tanpa Pemidanaan Dalam Perkara Tindak Pidana Korupsi, Pusat Studi Hukum dan Kebijakan Indonesia (PSHK) dan Pusat Penelitian dan Pengembangan Hukum dan Peradilan (Puslitbangkumdil) Mahkamah Agung Republik Indonesia, Jakarta. 
Imbar, Maggie Regina, Peran Jaksa Terhadap Asset Recovery Dalam Tindak Pidana Pencucian Uang, Jurnal Lex Crimen, Vol. IV, No.1, Januari-Maret 2015.

Pakpahan, Rudy Hendra dan Aras Firdaus, Pembaharuan Kebijakan Hukum Asset Recovery: Antara Ius Constitutum dan Ius Constituendum, Jurnal Legislasi Indonesia, Vol. 16, No. 3, September 2019.

Prakarsa, Aliyth dan Rena Yulia, Model Pengembalian Aset (Asset Recovery) Sebagai Alternatif Memulihkan Kerugian Negara Dalam Perkara Tindak Pidana Korupsi, Jurnal Hukum Prioris, Vol. 6, No.1, 2017.

Rahmayanti, Urgensi Civil Forfeiture Untuk Meningkatkan Pengembalian Kerugian Keuangan Negara, Jurnal Ilmu Hukum Prima Indonesia (IHP), Vol.1, No.1, April 2018

\section{Makalah}

Arief, Basrief, 2014, Pemulihan Aset Hasil Kejahatan dalam Pemberantasan Tindak Pidana Korupsi, Workshop Pemulihan Aset Tindak Pidana, Jakarta.

Suhariyono, AR, 2014, Rancangan Undang-Undang tentang Perampasan Aset Tindak Pidana, Workshop Pemulihan Aset Tindak Pidana, Jakarta.

\section{Hasil Penelitian}

Antoro, Bibianus Hengky Widhi, 2014, Tesis "Kebijakan Integral Pemberantasan Tindak Pidana Korupsi Melalui Asset Recovery”, Surakarta: Fakultas Hukum Universitas Sebelas Maret.

Pohan, Augustinus, et all., 2008, Pengembalian Aset Kejahatan, Pusat Kajian Anti Korupsi Fakultas Hukum Universitas Gadjah Mada, Yogyakarta

Ramelan, et all., 2012, Laporan Akhir Naskah Akademik Rancangan Undang-Undang Tentang Perampasan Aset Tindak Pidana, Pusat Perencanaan Pembangunan Hukum Nasional Badan Pembinaan Hukum Nasional Kementerian Hukum dan Hak Asasi Manusia Republik Indonesia, Jakarta.

\section{Peraturan Perundang-undangan}

Undang-Undang Nomor 8 Tahun 1981 tentang Kitab Undang-Undang Hukum Acara Pidana. (Lembaran Negara Republik Indonesia Tahun 1981 Nomor 76)

Undang-Undang Nomor 31 Tahun 1999 tentang Pemberantasan Tindak Pidana Korupsi. (Lembaran Negara Republik Indonesia Tahun 1999 Nomor 140)

Undang-Undang Nomor 39 Tahun 1999 tentang Hak Asasi Manusia. (Lembaran Negara Republik Indonesia Tahun 1999 Nomor 165) 
Undang-Undang Nomor 20 Tahun 2001 tentang Perubahan Atas Undang-Undang Nomor 31 Tahun 1999 tentang Pemberantasan Tindak Pidana Korupsi. (Tambahan Lembaran Negara Republik Indonesia Nomor 4150)

Undang-Undang Nomor 7 Tahun 2006 tentang Pengesahan United Nations Convention Against Corruption, 2003 (Konvensi Perserikatan Bangsa-Bangsa Anti Korupsi, 2003). (Lembaran Negara Republik Indonesia Tahun 2006 Nomor 32)

Undang-Undang Nomor 8 Tahun 2010 tentang Tindak Pidana Pencucian Uang. (Lembaran Negara Republik Indonesia Tahun 2010 Nomor 122) 